\title{
TUBERCULOSIS IN THE EUROPEAN UNION - ONGOING COMMITMENT NEEDED TO CONTROL THE DISEASE
}

Zsuzsanna Jakab ${ }^{1}$

1. European Centre for Disease Prevention and Control, Stockholm, Sweden

On 24 March 1882, the German microbiologist Robert Koch announced his discovery that the bacterium Mycobacterium tuberculosis caused tuberculosis (TB). He was awarded a Nobel prize for these findings in 1905. World TB day on 24 March commemorates this event and is an opportunity for a critical appraisal of the TB situation, for raising awareness and for joining forces in order to control the disease. It is estimated that every year, there are over nine million new cases of TB worldwide and around one and a half million people die from TB. Thus TB is still one of the most important infectious diseases causing death in humans.

In the European Union (EU), considerable progress has been made in preventing and controlling the disease: The number of newly diagnosed cases and the overall notification rate declined continuously in the past decade. The notification rate in 2007 was $12 \%$ lower than in 2003, which reflects a downward trend in 25 countries [1]. In spite of this decline, a total of 84,917 new cases of TB were registered in 2007 - half a century after the introduction of effective treatment - in the EU and the three countries in the European Economic Area/European Free Trade Association (EEA/ EFTA) Iceland, Liechtenstein and Norway.

In March 2009, the European Centre for Disease Prevention and Control (ECDC) and the World Health Organization Regional Office for Europe (WHO/Europe) publish their first joint report on the Surveillance of tuberculosis in Europe - 2007 since the coordination of the former EuroTB network moved to ECDC on 1 January 2008 and the two organisations started to perform joint surveillance.

While the figures from this report for the EU and EEA/EFTA countries are encouraging, they also highlight a number of challenges that hamper the progress towards the elimination of TB.

Multidrug-resistant (MDR) TB, a form of TB which is difficult to cure and laborious for the patient, and which requires considerable human and financial resources, threatens the goal of eliminating TB in Europe. High proportions of MDR TB - up to $21 \%$ of all TB cases - are observed in some EU countries. In this issue of Eurosurveillance an article by Anderson et al. shows trends in MDR TB in Scotland, a low incidence country for TB, over eight years and aims at identifying risk groups that need special attention [1]. A rapid communication based on the 2007 TB Surveillance report, shows a disparity in TB incidence within the EU [2], where the majority of countries are progressing towards elimination of the disease (defined as less than one case per 1,000,000 population per year) and where TB tends to accumulate in vulnerable populations with poor access to healthcare. An article by Mulder et al. illustrates relevant aspects of TB in individuals migrating form high incidence countries [3], and an article from Greece points out considerable underreporting for a particular region in this EU Member State [4].

The ECDC/WHO/Europe surveillance report also shows that some countries in the EU are still confronted with considerable numbers of newly diagnosed TB cases and notification rates from 36 to 118 cases per 100,000 population. These countries need particular support, and ECDC is closely collaborating with them to jointly face the challenges.

TB has been high on ECDC's agenda from start; the ECDC TB programme comprises a multi-disciplinary team of experts working together on all aspects of the disease to support the countries in their progress towards elimination of TB, a goal that requires sustained political commitment and equal access to early diagnosis, treatment and cure for all patients.

On request of the European Commission, ECDC will be supporting the follow-up of the Framework Action Plan to Fight Tuberculosis in the EU [5] in the coming months and will work closely with Member States and experts in the field to define the most effective manner of its implementation. We are certain that this will contribute to sustain the efforts towards TB elimination despite the obstacles that lie ahead.

\section{References}

1. Anderson LF, Laurenson IF, Blatchford O, Shakir E, McMenamin J, Johnston F, et al. Trends in multidrug-resistant tuberculosis in Scotland, 2000-7. Euro Surveill. 2009;14(11):pii=19149. Available from: http://www.eurosurveillance. org/ViewArticle.aspx?ArticleId=19149

2. Hollo V, Amato-Gauci A, Ködmön C, Manissero D. Tuberculosis in the EU and EEA/EFTA countries - what is the latest data telling us? Euro Surveill. 2009;14(11):pij=19151. Available from: http://www.eurosurveillance.org/ ViewArticle.aspx?ArticleId $=19151$

3. Mulder C, Klinkenberg E, Manissero D. Effectiveness of tuberculosis contact tracing among migrants and the foreign-born population. Euro Surveill. 2009;14(11):pii=19153. Available from: http://www.eurosurveillance.org/ ViewArticle.aspx?ArticleId $=19153$ 
4. Jelastopulu E, Alexopoulos EC, Venieri D, Tsiros D, Komninou G, Constantinidis TC, Chrysanthopoulos K. Substantial underreporting of tuberculosis in West Greece - implications for local and national surveillance. Euro Surveill. 2009;14(11):pii=19152. Available from: http://www.eurosurveillance.org/ ViewArticle.aspx?ArticleId $=19152$

5. Fernandez de la Hoz K, Manissero D, on behalf of the Tuberculosis Disease Programme. A Framework Action Plan to fight Tuberculosis in the European Union. Euro Surveill. 2008:13(12):pij=8074. Available from: http://www. eurosurveillance.org/ViewArticle. aspx?ArticleId $=8074$.

This article was published on 19 March 2009.

Citation style for this article: Jakab Z. Tuberculosis in the European Union - ongoing commitment needed to control the disease. Euro Surveill. 2009;14(11):pij=19150. Available online: http://www.eurosurveillance.org/ViewArticle.aspx?ArticleId=19150 